Tropical Journal of Pharmaceutical Research December 2017; 16 (12): 2801-2809

ISSN: 1596-5996 (print); 1596-9827 (electronic) (1) Pharmacotherapy Group, Faculty of Pharmacy, University of Benin, Benin City, 300001 Nigeria.

\title{
Production of a phage-displayed single chain variable fragment antibody against infectious bursal disease virus
}

\author{
Amir Shabdini Pashaki ${ }^{1}$, Mohammad Reza Safarnejad ${ }^{2 \star}$, Amir Hossein Asgari \\ Safdar $^{3}$, Hosein Safarpour ${ }^{4}$, Meisam Tabatabaie ${ }^{5}$ \\ ${ }^{1}$ Department of Animal Science, Science and Research Branch, Islamic Azad University, Tehran, Iran, ${ }^{2}$ Iranian Research \\ Institute of Plant Protections, Agricultural Research, Education and Extension Organization (AREEO), Tehran, Iran, ${ }^{3}$ Young \\ Researchers and Elite Club, Baft Branch, Islamic Azad University, Baft, Iran, ${ }^{4}$ Cellular and Molecular Research Center, Birjand \\ University of Medical Sciences, Birjand, Iran, ${ }^{5}$ Microbial biotechnology Department, Agricultural Biotechnology Research \\ Institute of Iran (ABRII), Agricultural Research, Education and Extension Organization (AREEO), Karaj, Iran
}

*For correspondence: Email: mrsafarnejad@yahoo.com; Tel: +98 21 22403012-16

Sent for review: 1 September 2017

Revised accepted: 27 November 2017

\begin{abstract}
Purpose: To develop specific single chain variable fragments (scFv) against infectious bursal disease virus (IBDV) via phage display technology.

Methods: Purified viruses were initially applied for iterative panning rounds of scFv phage display libraries. The binding ability of the selected scFv antibody fragments against the IBDV particles was analyzed by indirect enzyme-linked immunosorbent assay (ELISA) followed by blotting assays. Threedimensional (3D) structure of the selected scFv antibody fragment and VP3 protein were predicted through in silico analysis. Structural characterization of the antibody-antigen complexes was carried out by computational docking analysis.

Results: The serological results obtained from the ELISA and blotting analysis showed that the selected clones produced specific scFv antibody fragments that were capable of effectively detecting infectious bursal disease (IBD) in the infected animal tissue. Biodiversity analysis by BstNI finger printing and nucleotide sequencing revealed that there was no major difference in nucleotide sequences of the selected clones. Further analysis demonstrated that this recombinant fragment of the antibody was able to bind to VP3 structural protein of IBDV with a molecular weight of $\sim 30 \mathrm{kDa}$. Molecular docking results revealed that the binding energy of scFV to IBDV-VP3 was $545 \mathrm{kj} / \mathrm{mol}$.

Conclusion: The developed scFV antibody fragments possess great potentials for the diagnosis of IBD. The findings of the present study confirm the feasibility of using phage display technology for rapid production of antibodies against IBD diseases by applying naïve scFv libraries.
\end{abstract}

Keywords: Antibody, Molecular docking, Phage display technology, Single chain variable fragments

\begin{abstract}
This is an Open Access article that uses a funding model which does not charge readers or their institutions for access and distributed under the terms of the Creative Commons Attribution License (http://creativecommons.org/licenses/by/4.0) and the Budapest Open Access Initiative (http://www.budapestopenaccessinitiative.org/read), which permit unrestricted use, distribution, and reproduction in any medium, provided the original work is properly credited.

Tropical Journal of Pharmaceutical Research is indexed by Science Citation Index (SciSearch), Scopus, International Pharmaceutical Abstract, Chemical Abstracts, Embase, Index Copernicus, EBSCO, African Index Medicus, JournalSeek, Journal Citation Reports/Science Edition, Directory of Open Access Journals (DOAJ), African Journal Online, Bioline International, Open-J-Gate and Pharmacy Abstracts
\end{abstract}

\section{INTRODUCTION}

Infectious bursal disease (IBD), commonly known as gumboro, is one of the most important viral diseases in the poultry industry throughout the world [1]. The economic losses associated with IBD are caused by both increased rate of mortality and the immunosuppressive effects of 
the disease on infected animals. The disease is caused by infectious bursal disease virus (IBDV), a double stranded (ds) RNA virus belonging to the genus Avibirnavirus under the family Birnavirdae. The virus is normally present within the bursa of Fabricius as well as other organs such as skeletal muscle, intestines, kidney, and spleen. Two serotypes of the virus have been isolated from chickens; serotype I is pathogenic with high antigenicity whereas serotype II is not pathogenic and is not followed by any clinical signs or immunosuppression [2].

Gumboro has no treatments or drugs and therefore, it is important to try to prevent the disease by observing strict hygienic and vaccination programs [3]. Nevertheless, application of vitamins as well as antibiotics can prevent subsequence infections $[4,5]$.

Since Gumboro has been reported all around the world and that it spreads rapidly, constant monitoring and early detection of the disease is of crucial importance. This could be achieved based on clinical symptoms, flock history, and necropsy approaches. However, accurate detection can only be accomplished by applying diagnostic methods such as in situ hybridization, immunofluorescence, immunohistochemistry, RT-PCR, and enzyme-linked immunosorbent assay (ELISA) [2].

Nowadays, poly- and monoclonal antibodies play a major role in the detection of many kinds of diseases. Monoclonal antibodies have several advantages over their polyclonal counterparts including higher specificity and more accuracy. However, the production of monoclonal antibodies is usually more time-consuming and complicated compared with polyclonal antibodies. Recombinant antibody technology is an efficient approach for the production of target-specific monoclonal antibodies through the application of the phage display technology [6]. This technology has been employed for developing several monoclonal recombinant antibodies against a wide range of antigens [712]. Therefore, the present study was aimed at developing an IBDV-specific monoclonal recombinant antibody from the Tomlinson I antibody library by using the phage display technique.

\section{EXPERIMENTAL}

\section{Source of virus}

The virus isolate used in this study was a commercial IBDV vaccine provided by the Razi Vaccine and Serum Research Institute (RVSRI)
(Arak, Iran). This vaccine was an attenuated form of an Iranian isolate of IBDV emulsified in montanide oil. The pre-confirmed IBDV-infected (as positive control) and healthy (as negative control) chicken bursa tissues were also prepared and provided by the RVSRI.

\section{Panning of phage display libraries}

Specific scFv antibody fragments were isolated from naïve Tomlinson I scFv phage display libraries by applying the IBDV vaccine as described earlier [13]. IBDV particles were immobilized onto immunotubes (Nunc-Maxisorp, Denmark) followed by blocking with $2 \%$ (v/v) skimmed milk and incubation with the phage suspension $\left(\sim 10^{13}\right.$ CFU). The bound phage particles were eluted from the surface of the immunotubes by adding $1 \mathrm{ml} 100 \mathrm{mM}$ triethylamine followed by adding $0,5 \mathrm{ml} 1 \mathrm{M}$ Tris, $\mathrm{pH}=7,5$. The eluted phage particles were then amplified in exponentially-growing $E$. coli TG1 and were purified by PEG precipitation. The panning step was repeated three times. After the third round of panning, individual clones expressing phages or soluble scFv antibody fragments were randomly selected and tested for binding specificity against IBDV by ELISA.

\section{Mini-induction of ScFv}

For low scale production of soluble scFv antibody fragment, after the third round of panning, ninety six colonies (HB2151 non-suppressor strain of $E$. coli) were randomly selected and cultured in a 96-well plate. Expression of scFv gene was initiated by addition of isopropyl- $\beta$-Dthiogalactoside (IPTG) to a final concentration of $0.5 \mathrm{mM}$ followed by incubation at $30{ }^{\circ} \mathrm{C}$ overnight. The cells were isolated by centrifugation and supernatants were used for subsequent assays.

\section{Binding activity of scFv against}

The specificity of produced ScFv antibody fragments was analyzed by ELISA as described earlier [14]. Around $100 \mu$ l of IBDV vaccine (50 $\mu \mathrm{g} / \mathrm{mL}$ ) diluted in 1x PBS was loaded on ELISA plates (Maxisorp, Nunc, Denmark). Blocking step was performed by adding same amount of 1xPBS containing $2 \%$ Marvel (2\% MPBS). About $100 \mu \mathrm{L}$ of expressed scFv antibody fragment were added into the wells and plates were incubated for $2 \mathrm{~h}$ at $37^{\circ} \mathrm{C}$. The specific binders were detected by using $100 \mu$ of $1: 1000$ diluted mouse anti-c-myc monoclonal antibody 9E10 followed by adding same amount of 1:10000 diluted horseradish peroxidase (HRP) conjugated to goat-anti-mouse polyclonal 
antibodies. $100 \mu$ l of ABTS substrate (2,2'-azinodi-(3-ethylbenzthiazoline sulfonic acid)) was used for colour development at room temperature for 30 minutes. After that, the absorbance values at $405 \mathrm{~nm}\left(\mathrm{OD}_{405} \mathrm{~nm}\right)$ was measured using a micro plate reader (ELx808 Absorbance Microplate Reader, Winooski, VT, USA). Colonies expressing ScFv fragments with high binding ability against IBDV particles were selected and subjected to further analysis.

\section{Western blotting}

For Western blotting, protein bands were initially separated on SDS-PAGE and transferred to PVDF nitrocellulose membrane. Blocking of membrane was performed with 1XPBS containing $2 \%$ Marvel (2 \% MPBS). The bacterially-expressed scFv fragment was used for detection. The banding of ScFv antibody fragment to protein was revealed by $1: 1000$ diluted anti-c-myc 9E10 monoclonal antibody followed by 1:10000 diluted goat-antimouse IgG conjugated to alkaline phosphatase $\left(G^{A} M^{A P}\right)$. Binding of antibody molecules to antigen was visualized by using a substrate containing nitro blue tetrazolium chloride (NBT) and 5-bromo-4chloro-3-indolyl phosphate (BCIP).

\section{Homology modeling}

Three-dimensional (3D) structure of the IBDV (PDB ID: 2r18A, RCSB database) was retrieved. Tertiary structure of the anti-IBDV scFv was modeled by subjecting its amino acid sequences to the I-TASSER (https://zhanglab.ccmb.med. umich.edu/l-TASSER/). This internet based server generates 3D models by collecting highest scoring and ranking of template models based on the target model amino acid sequence. The confidence score (C-score) used to estimate the quality of the I-TASSER-developed models is typically in a range of -5 to +2 . Higher C-score values reveal the quality of a given model.

\section{Molecular docking}

In order to investigate the mode of interaction between the IBDV 3D and the anti-IBDV ScFv model, molecular docking was performed by BioLuminate module of the Schrodinger suite (version 1.9, Schrodinger, LLC, New York, NY). The possible interactions were analyzed using the Pymol software (The PyMOL Molecular Graphics System, version $1.3 \mathrm{r} 1$ edu, Schrodinger, LLC). The final model was selected based on the cluster size as described in the results session.

\section{RESULTS}

\section{Phage display ScFv selection}

To obtain specific scFv recombinant antibody, iterative round of panning were performed by using around $10^{13} \mathrm{cfu}$ of recombinant phages. Upon the completion of every round of panning, the population of the eluted phages was evaluated. Table 1 tabulates the enrichment of IBDV-specific scFv antibody fragments achieved through the panning processes. A rising titer of the eluted phages throughout the panning rounds shows that the number and the specificity of the eluted phages were increased consequently.

Table 1: Enrichment of specific scFv antibody fragments to IBDV through three rounds screening of Tomlinson phage display library

\begin{tabular}{lcc}
\hline Round of panning & Input phage & Output phage \\
\hline 1 & $10^{13}$ & $1.5 \times 10^{6}$ \\
2 & $10^{13}$ & $2.5 \times 10^{\prime}$ \\
3 & $10^{13}$ & $3.7 \times 10^{8}$ \\
\hline
\end{tabular}

After performing panning procedure, around 96 colonies were randomly selected and expressed in bacterial host. Indirect ELISA was performed for analysis binding activity of expressed ScFV fragments against IBDV. These results show that around $10 \%$ of selected clones produce ScFV antibody fragments with positive activity against the IBDV particles (Figure 1). These positive clones were then used for further analysis.

\section{PCR results and BstNI fingerprint of individual phage clones}

To determine the variability of the selected clones, the scFv genes were PCR amplified by using specific pHEN primers and were then subjected to BstNI fingerprinting. All the analyzed clones showed an insert of about 850 bp (Figure 2A). Subsequent digestion patterns revealed only one type of band present in all samples (Figure $2 B$ ). These results proved the high similarity of the selected scFv genes.

Furthermore, the sequencing results confirmed that there was no major difference in the nucleotide sequences of the selected clones. Three complementary determining regions (CDRs) and 4 framework (FW) regions were identified in each $\mathrm{VH}$ and $\mathrm{VL}$ fragments. The selected ScFv antibody fragments had open reading frames encoding proteins with a molecular weight of $28 \mathrm{kDa}$. The FW and CDRs were determined according to the IMGT databases (http://imgt.cines.fr/IMGT_vquest/). 


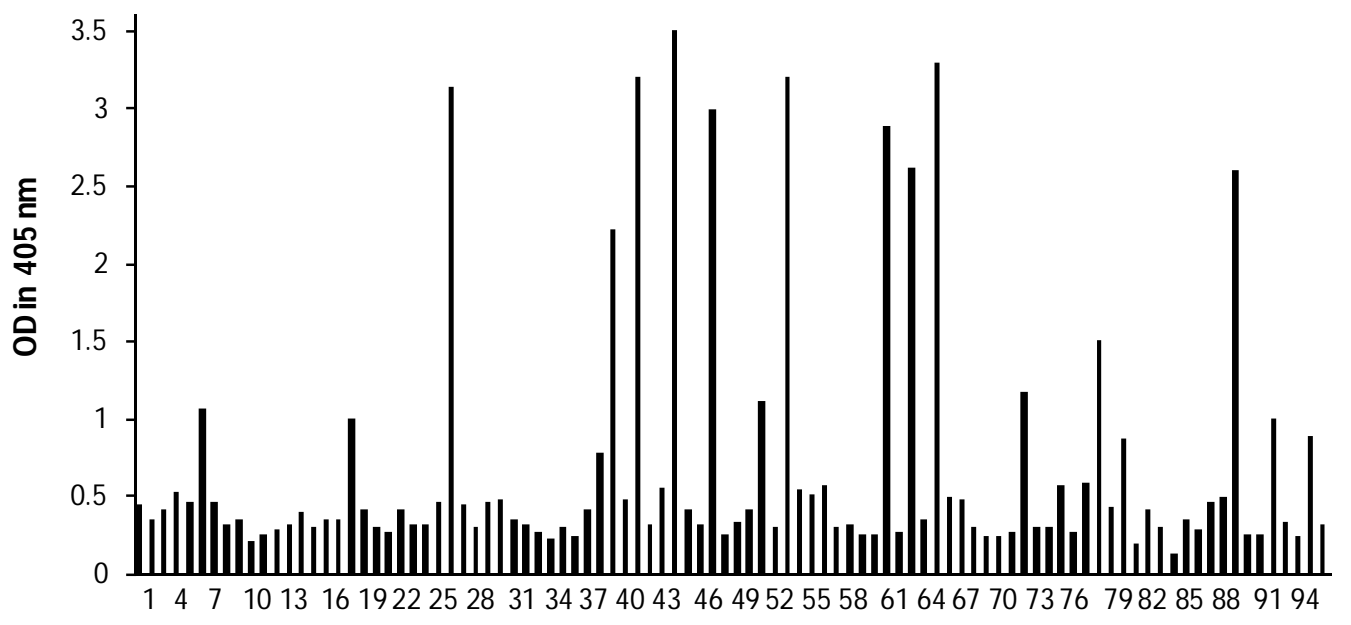

\section{Clone number}

Figure 1: Indirect ELISA analysis for screening of the randomly selected clones from the Tomlinson I scFv library. After the third round of panning, the ScFv antibody fragments expressed from selected clones was analyzed for binding activity against IBDV. The IBDV vaccine was coated on microtitre plates followed by blocking by $2 \%$ MPBS. The specific scFvs were detected by using $9 \mathrm{E} 10$ monoclonal antibody, and goat antimouse polyclonal antibody conjugated to horse radish peroxidase $\left(\mathrm{GAM}^{\mathrm{HRP}}\right)$ as secondary antibody. After 30 minutes the absorbance values at $405 \mathrm{~nm}\left(\mathrm{OD}_{405} \mathrm{~nm}\right)$ was measured using a micro plate reader (ELx 808 Absorbance Microplate Reader, Winooski, VT, USA)
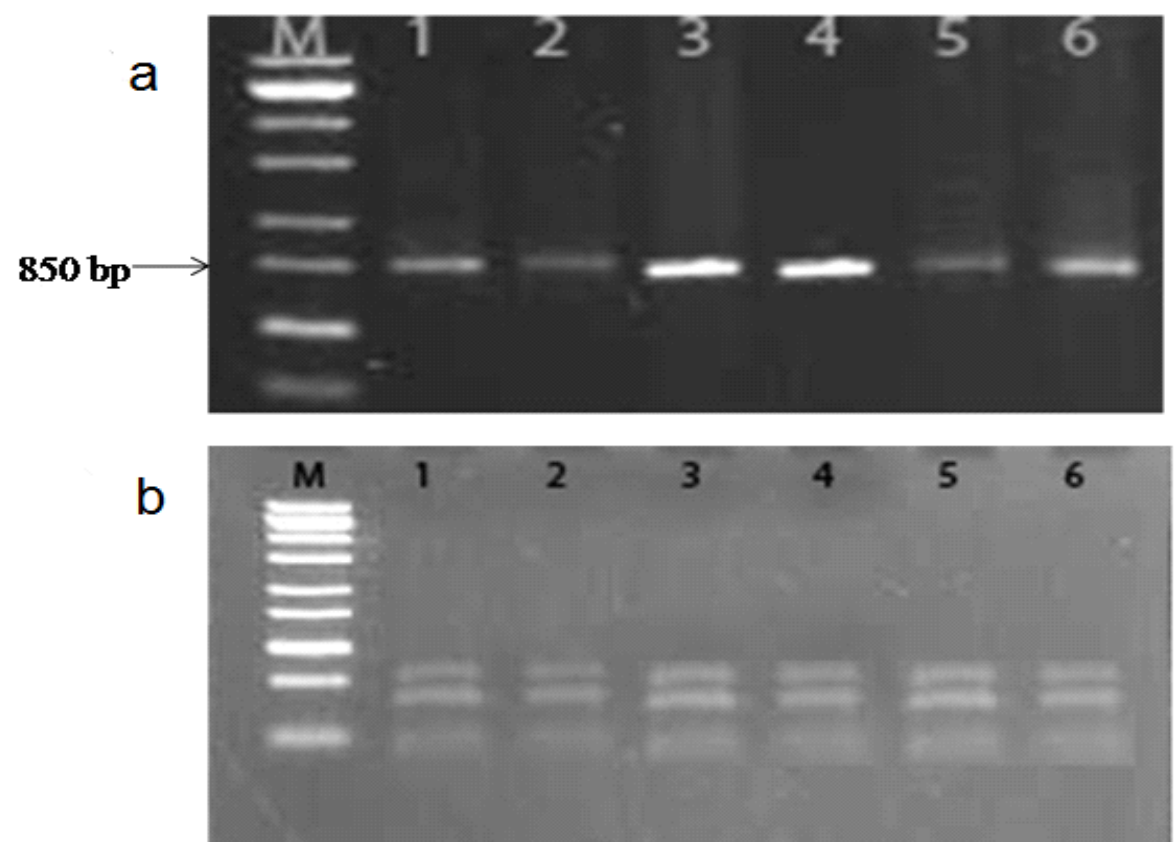

Figure 2: (a) Analysis of the amplified fragment through PCR analysis of the IBDV binder clones from Tomlinson I phage display library. The PCR products were separated on a $1 \%(\mathrm{w} / \mathrm{v})$ agarose gel. 1:1 Kb ladder 1-9: patterns of 6 selected clones reacting to IBDV. (b) Finger printing analysis of the IBDV binder clones selected from Tomlinson I phage display library. The genes encoding scFv fragments were initially amplified by using specific pHEN primers and amplified fragments subjected to BstNI digestion. Samples were analyzed on a $2 \%(\mathrm{w} / \mathrm{v})$ agarose gel. 1-6: RFLP patterns of 6 selected clones, M: DNA ladder

\section{Serological analysis}

To determine the specificity of the prepared scFv antibody fragments against the IBDV-infected chickens, the soluble scFv recombinant antibody expressed from the selected clones (scFv-c2,
scFv-E5, scFv-F1, scFv-F3 and scFv-F5) were further analyzed by the ELISA and Western blotting. The IBDV-infected chicken bursa was used as positive control. The ELISA results revealed that all selected $\mathrm{ScFv}$ fragment antibodies has a high reactivity against IBDV 
particles present in the vaccine and in the infected bursa (Figure 3). There was no cross reaction with the extract of healthy bursa nor with the BSA protein as negative control.

Complementary Western blot analysis reconfirmed the specificity of the selected scFv clone (scFv-c2) against IBDV (Figure 4). This finding revealed the presence of a specific antigen with a molecular weight of around $30 \mathrm{kDa}$, strongly bound to the scFv monoclonal antibody. Furthermore, the positive response obtained in the Western blot analysis indicated that the corresponding epitope is a continuous type presented in both the vaccine and the native protein.

\section{Homology model building and validation}

To predict the 3-D structure of the anti-IBDV scFv, the cognate amino acid sequence was applied to the I-TASSER server. The PDB file $5 \mathrm{~F} 72 \mathrm{~T}$ was selected as the best template model based on the highest similarity (in the case of 5F72: $79 \%$ identity) and C-score (in the case of 5F72T: 0.3) and least RMSD value (in the case of 5F72: $5.9 \pm 3.7 \AA$ ) (Figure $5 A$ ). The quality of the refined model was evaluated by a psi/phi Ramachandran plot using BioLuminate. Figure $5 \mathrm{~B}$ shows that about $92 \%$ of the amino acid residues were in the most favored regions and only $2 \%$ were in the disallowed regions. Due to the lack of appropriate crystal structure in the (Glycine ${ }_{4}$ Serine $)_{3}$ linker, the unfavorable residues were mainly located in this region of the model. These results indicated that the scFv model was suitable for the molecular docking study.

\section{Docking of IBDV with ScFv}

To visualize the interaction of the scFv with IBDV, the most stable form of the antigen, $2 \mathrm{r} 18 \mathrm{~A}$ model, was docked onto 5F72T scFv model using Bioluminate program. The suggested model with the lowest energy docking (among 30 models) was selected. According to the docking results, the binding energy of the scFv was estimated to be at $-545 \mathrm{~kJ} / \mathrm{mole}$ when bonded to IBDV. The final configuration of the docking complex of the scFv-IBDV is shown in Figure 6 revealing the binding of the IBDV molecule to the gap between the $\mathrm{VL}$ and $\mathrm{VH}$ domains of the scFv.

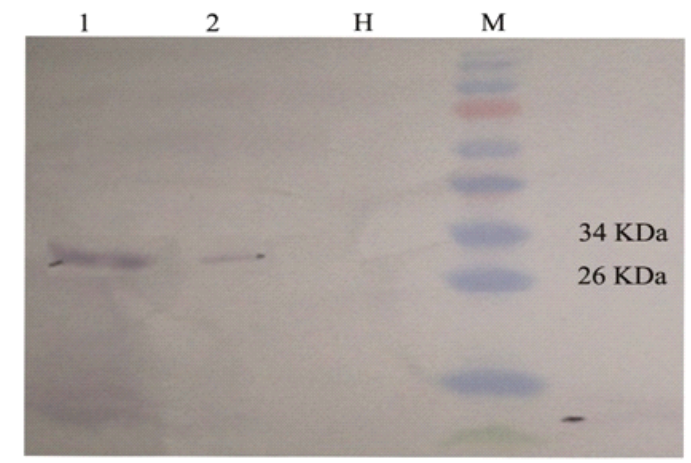

Figure 4: Western blot analysis of the bacteriallyexpressed scFV-c2 against IBDV-infected animal tissue. The purified IBDV vaccine and the extracts of the infected and healthy bursa were separated on a 12 $\%$ (w/v) SDS-PAGE gel. Proteins were blotted onto a nitrocellulose membrane and the bacterially-expressed scFv-c2 was used for detection. The banding was revealed by $9 \mathrm{E} 10$ monoclonal antibody and GAMAP antibody conjugated to alkaline phosphatase followed by staining with NBT/BCIP. 1: IBDV vaccine; 2 : extract of infected bursa; $\mathrm{H}$ : extract of healthy bursa; M: Prestained protein marker

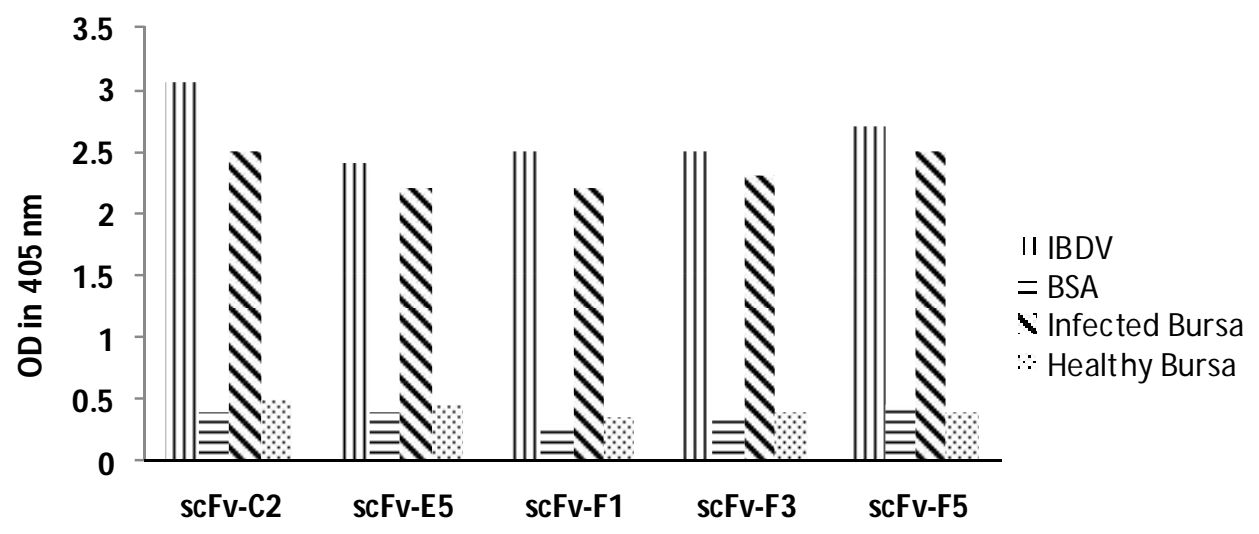

Figure 3: ELISA results showing the reactivity of the bacterially-expressed ScFv fragments against IBDV antigens (vaccine and infected bursa). Binding of scFv fragments to cognate antigen was detected by using $9 \mathrm{E} 10$ monoclonal antibody, and goat anti-mouse polyclonal antibody conjugated to horse radish peroxidase (GAM $\left.{ }^{\mathrm{HRP}}\right)$ as secondary antibody. After 30 minutes the absorbance values at $405 \mathrm{~nm}\left(\mathrm{OD}_{405} \mathrm{~nm}\right)$ was measured using a micro plate reader (ELx808 Absorbance Microplate Reader, Winooski, VT, USA) 

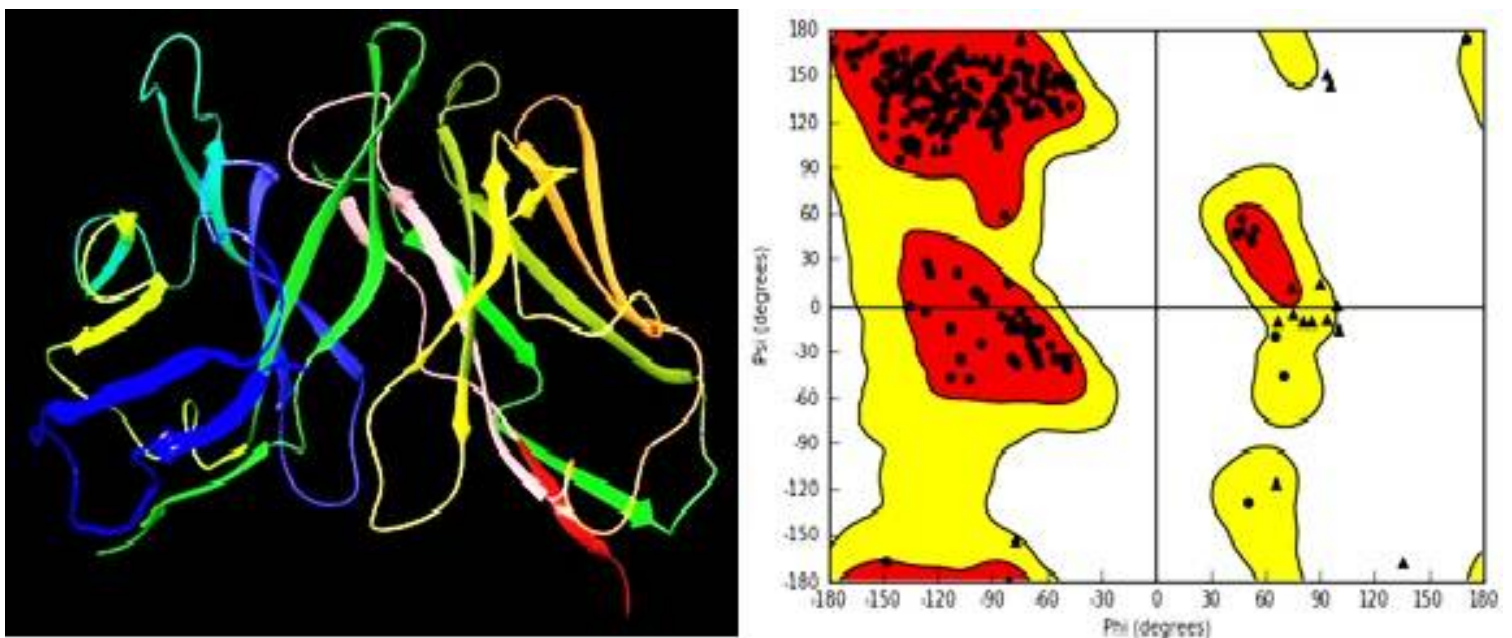

Figure 5: Three-dimensional homology model of anti IBDV scFv. (A) 3D model of scFv of IBDV. (B) Ramachandran plot of the scFv model

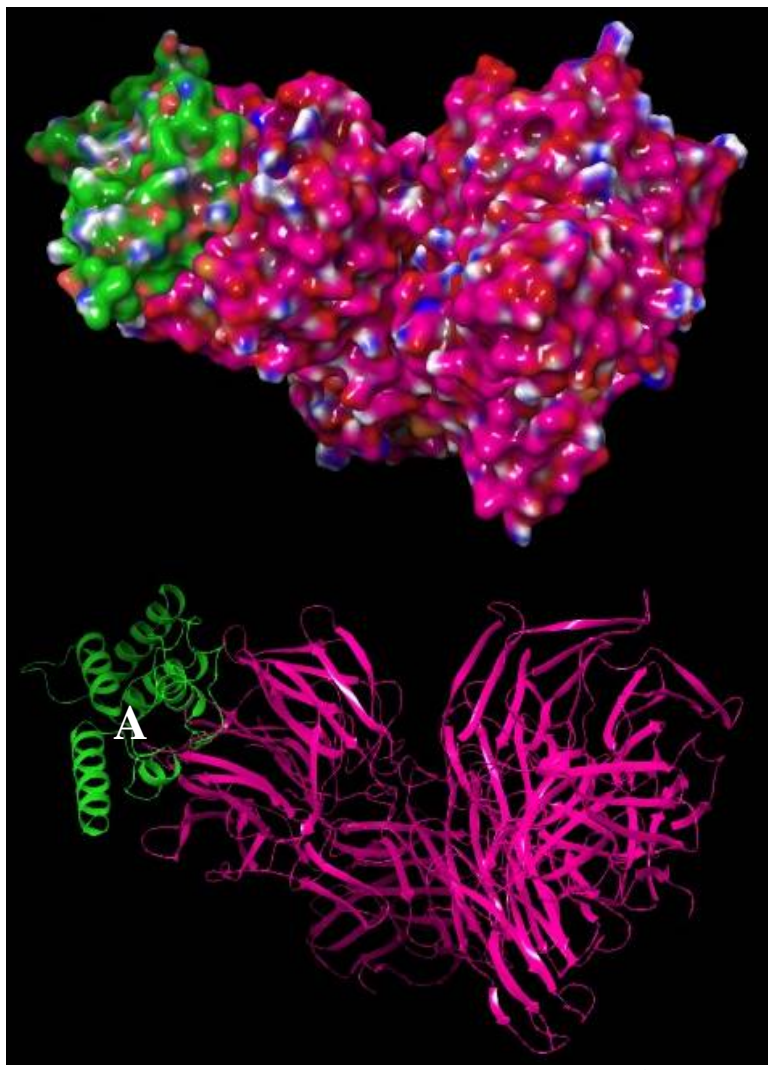

Figure 6: Three-dimensional binding poses of docking complex of the scFv for IBDV. The surface $(A)$ and cartoon $(B)$ 3D binding poses

\section{DISCUSSION}

IBDV is among the major pathogens imposing high economic losses on the poultry industry worldwide. The present study strived to develop a recombinant antibody fragment against IBDV using molecular biology and genetic engineering. Based on the findings obtained herein, the recombinant antibodies could successfully be used for efficient diagnosis of the diseases [11,15-18].

Phage display technology provides a straightforward approach for selection of specific recombinant antibody fragments with highest affinity for the target antigen from a huge number of variants in antibody libraries [19]. On that basis, in the present study, this technology was applied to isolate new antibodies against the IBDV virions from Tomlinson I naïve nonimmunized antibody libraries. The isolated scFv antibody fragments were expressed in bacterial cells and were successfully used in typical diagnostic applications such as immunoblotting and ELISA.

Western blot data showed that the selected scFv antibody fragment strongly bound to a protein with molecular weight of $30 \mathrm{kDa}$ (Figure 4). The IBDV capsid is mainly composed of VP2 and VP3 proteins. Hudson et al [20] showed that the IBDV encodes a $106 \mathrm{kDa}$ polyprotein that is later processed to three mature proteins VP2 $(50 \pm 52$ $\mathrm{kDa}), \operatorname{VP} 3(30 \pm 32 \mathrm{kDa})$, and VP4 $(27 \pm 30$ $\mathrm{kDa})$. It seems that the VP3 capsid protein of the IBDV with a molecular weight of $30 \mathrm{kDa}$ is the binding partner of the selected scFv fragment monoclonal antibody.

The developed $\mathrm{scFv}$ antibody fragments were shown to offer great potentials for diagnosis of gumboro disease. The findings of this study confirmed the feasibility of using the phage display technology for the rapid development of antibodies against IBD diseases by applying of naïve scFv libraries. In better words, the naïve non-immunized phage display libraries can be applied for the selection of specific antibody fragments elevating the need for animal immunization [13,21]. In the phage display 
libraries, billions of peptides capable binding to different antigens are present on the surface of the bacteriophages. Screening and panning techniques will recover the specific antibody gene [22]. This technique is simple, cheap, and rapid and requires no special equipment. Moreover, because of elimination of the immunization stage from this technology, it does not involve ethical concerns related to animal use and scarification either [21].

The ability of the selected ScFv antibody fragments to bind the corresponding antigens in both ELISA and blotting analysis confirm their specificity. The positive results obtained through the Western blot analysis confirmed the presence of the corresponding binding site (epitope) in the IBDV virions as a continuous epitope [23].

To the best of our knowledge, this is the first report on the construction of a monoclonal antibody against IBDV through non-immunized phage display libraries. Nevertheless, there are several reports on developing specific IBDV recombinant antibodies by applying chicken preimmunized library and/or bacterial libraries. Zhang et al [11] described the application of bacterial display for isolation of ScFv antibody fragments against IBDV from an antibody library via the VP2 protein. Sapats et al [24] developed two chicken scFv antibody fragments reacting with high virulent strains of IBDV. They argued that their method was 8-16 to times more sensitive for IBDV antigen detection than the mouse monoclonal antibody ELISA.

These serological results revealed that scFv could be used as highly specific and sensitive ELISA reagents for the detection of avian pathogens. In fact, the power of recombinant antibodies over previously described conventional methods, for fine antigenic differentiation and to provide a sensitive, specific, and simple platform has been well confirmed [24]. In another study, phage display technology was used for the isolation of a specific scFv antibody from the immune spleen cells of chickens immunized with a high virulent strain of IBDV [12].

Sapats et al [1] developed a number of scFv recombinant antibodies by biopanning of a phage-display libraries derived from the spleen of chickens immunized with an Australian strain of IBDV. These scFvs showed a significant potential for the discrimination of different IBDV strains and neutralizing capacity. Xu et al [10] used the bacteria display technology and produced a recombinant ScFv antibody by flow cytometry against VP2 protein from the chickens immunized with VP2 protein of IBDV. They obtained three scFv clones with different fluorescence intensity by random colony pick up after biopanning of the bacteria displayed antibody library. Subsequently, they investigated the feasibility of using the selected IBDV-specific scFv antibodies against the virus by the application of the isolated antibodies in Western blotting assay and ELISA.

Homology modeling and molecular docking are two appropriate computational methods to investigate protein-ligand interactions. Herein, the user-friendly internet based server 'ITASSER' was used for homology modelling and generation of a reliable 3D structure. PDB file of 5F72T molecular model was used as input model in the antigen-antibody docking. Thirty models were generated by the BioLuminate program and the model with the highest rank was selected for the analysis. Docking results of the scFv-IBDV showed a binding energy of $-545 \mathrm{kj} / \mathrm{mol}$.

The recombinant antibody fragments could also be used for developing more sophisticated diagnostic tools such as biosensors and nanobiosensors. For instance, Mechaly et al [25] applied scFv based biosensor for the efficient and specific detection of $B$. anthracis spores. Moreover, since the scFv antibody possesses a binding ability to antigens, thus it could be potentially used as unique molecule to be fused to other toxins/antigens in treatment procedures [26]. For instance, the anti-fAChR immunotoxin (scFv35-ETA) is a fusion of anti-fAChR Fabfragment to Pseudomonas exotoxin A and has been used for the treatment of fatal neoplasm [27].

\section{CONCLUSION}

The recombinant antibodies developed in the present study easily detect IBDV-infected animals and, therefore, can be applied for diagnostic purposes using conventional diagnostic platforms such as ELISA and dot blot assays. Furthermore, the developed antibodies can potentially be used for developing more sensitive diagnostic tools as well, for example, biosensors and nanobiosensors.

\section{DECLARATIONS}

\section{Acknowledgment}

The authors appreciate the financial support provided by Iran National Science Foundation (INSF) for this work. 


\section{Conflict of interest}

No conflict of interest is associated with this work

\section{Contribution of authors}

We declare that this work was done by the authors named in this article and all liabilities pertaining to claims relating to the content of this article will be borne by the authors.

\section{REFERENCES}

1. Sapats S, Heine H, Trinidad L, Gould G, Foord A, Doolan $S$, Prowse S, Ignjatovic J. Generation of chicken single chain antibody variable fragments (scfv) that differentiate and neutralize infectious bursal disease virus (ibdv). Arch Virol 2003; 148: 497-515.

2. Eterradossi N, Saif $Y M$. Infectious bursal disease. In: Diseases of Poultry. Y.M. Saif, AM Fadly, JR Glisson, LR McDougald, LK Nolan, D.E. Swayne. Editors. WileyBlackwell, Ames. 12th ed. IA, USA; 2008; pp 185-208

3. Deb R, Dey S, Mohan CM, Gaikwad S, Kamble N, Khulape SA, Gupta SK, Maity HK, Pathak DC. Development and evaluation of a salmonella typhimurium flagellin based chimeric DNA vaccine against infectious bursal disease of poultry. Res Vet Sci 2015; 102: 7-14.

4. Farooq A, Rabbani M, Muhammad K, Akram Z, Ahad A, Fatima Z, Kamal T, Anwar Z. Passive immunization in infectious bursal disease virus infected birds using chemically purified immune yolk immunoglobulins (IgY). Afr J Microbiol Res 2012; 6: 2993-2998.

5. Keller MA, Stiehm ER. Passive immunity in prevention and treatment of infectious diseases. Clin Microbiol Rev 2000; 13: 602-614.

6. Kirakosyan A, Kaufman PB. Recent advances in plant biotechnology. Dordrecht: Springer; 2009; $p 405$.

7. Safarnejad MR, Fischer $R$, Commandeur $U$. Recombinant-antibody-mediated resistance against tomato yellow leaf curl virus in nicotiana benthamiana. Arch Virol 2009; 154: 457-467.

8. Krishnaswamy S, Kabir ME, Rahman MM, Miyamoto M, Furuichi $Y$, Komiyama $T$. Isolation and characterization of recombinant single chain fragment variable antiidiotypic antibody specific to Aspergillus fumigatus membrane protein. J Immunol Methods 2011; 366: 6068.

9. Hu ZQ, Liu JL, Li HP, Xing S, Xue S, Zhang JB, Wang $J H$, Nölke $G$ Liao YC. Generation of a highly reactive chicken-derived single-chain variable fragment against fusarium verticillioides by phage display. Int $\mathrm{J} \mathrm{Mol} \mathrm{Sci}$ 2012; 13: 7038-7056.

10. Xu LM, Li TH, Zhou B, Guo M, Liu M, Zhao JZ, Cao HW, Li DS. Scfv antibodies against infectious bursal disease virus isolated from a combinatorial antibody library by flow cytometry. Biotechnol Lett 2014; 36: 1029-1035.
11. Zhang Y, Yin J, Li T, Zhou B, Xu P, Che R, Liu Y, Cao H, $Y e X$, Yang $Y$. A recombinant avian antibody against vp2 of infectious bursal disease virus protects chicken from viral infection. Res Vet Sci 2017; 114: 194-201.

12. Sapats S, Trinidad L, Gould G, Heine H, Van Den Berg T, Eterradossi $N$, Jackwood $D$, Parede L, Toquin $D$, Ignjatovic, J. Chicken recombinant antibodies specific for very virulent infectious bursal disease virus. Arch Virol 2006; 151: 1551-1566.

13. Safarnejad MR, Fischer R, Commandeur U. Generation and characterization of functional recombinant antibody fragments against tomato yellow leaf curl virus replication-associated protein. Commun Agri Appl Biol Sci 2008; 73: 311-323.

14. Shahryari F, Shams-Bakhsh M, Safarnejad MR, Safaie N, Ataei Kachoiee S. Preparation of antibody against immunodominant membrane protein (imp) of candidatus phytoplasma aurantifolia. Iranian J Biotechnol 2013; 11: 14-21.

15. Chen Y, Zhu X, Zhang X, Liu B, Huang L. Nanoparticles modified with tumor-targeting scfv deliver sirna and mirna for cancer therapy. Mol Ther 2010; 18: 16501656.

16. Staneloudi C, Smith KA, Hudson R, Malatesti N, Savoie $H$, Boyle RW, Greenman J. Development and characterization of novel photosensitizer: Scfv conjugates for use in photodynamic therapy of cancer. Immunology 2007; 120: 512-517.

17. Beck A, Reichert JM, Wurch T. In 5th European antibody congress 2009: November 30-December 2, 2009, Geneva, Switzerland, MAbs, 2010; Taylor \& Francis: pp 108-128.

18. Aggarwal S. Corrigendum: What's fueling the biotech engine-2007. Nat Biotechnol 2009; 27: 205-205.

19. Conrad U, Scheller J. Considerations on antibody-phage display methodology. Comb Chem High Throughput Screen 2005; 8: 117-126.

20. Azzam O, Frazer J, de la Rosa D, Beaver JS, Ahlquist P, Maxwell DP. Whitefly transmission and efficient ssdna accumulation of bean golden mosaic geminivirus require functional coat protein. Virology 1994; 204: 289-296.

21. Willats WG. Phage display: Practicalities and prospects. Plant Mol Biol 2002; 50: 837-854.

22. Safarnejad MR, Jouzani GS, Tabatabaie M, Twyman RM Schillberg S. Antibody-mediated resistance against plant pathogens. Biotechnol Adv 2011; 29: 961-971.

23. Forsström $B$, Axnäs $B B$, Rockberg J, Danielsson $H$, Bohlin A, Uhlen M. Dissecting antibodies with regards to linear and conformational epitopes. PloS One 2015; 10(3): e0121673.

24. Sapats S, Gould G, Trinidad L, Parede L, David C, Ignjatovic J. An elisa for detection of infectious bursal disease virus and differentiation of very virulent strains based on single chain recombinant chicken antibodies. Avian Pathol 2005; 34: 449-455.

25. Mechaly A, Zahavy E, Fisher M. Development and implementation of a single-chain $f v$ antibody for specific 
detection of bacillus anthracis spores. Appl Environ Microbiol 2008; 74: 818-822.

26. Ahmad ZA, Yeap SK, Ali AM, Ho WY, Alitheen NBM Hamid M. Scfv antibody: Principles and clinical application. Clin Dev Immunol 2012; 2012:980250.

27. Gattenloehner $S$, Jörissen $H$, Huhn $M$, Vincent $A$, Beeson $D$, Tzartos S, Mamalaki A, Etschmann B, Muller-
Hermelink $H$, Koscielniak E. A human recombinant autoantibody-based immunotoxin specific for the fetal acetylcholine receptor inhibits rhabdomyosarcoma growth in vitro and in a murine transplantation model. Biomed Res Int 2010; 2010. 